\title{
Pedagogical Aspects Related to the Prevention of Professional Marginalism as a Dangerous Psychological Phenomenon in Educational Process at Departmental Universities
}

\author{
LYUBOV' V. KOVTUNENKO \\ Research Institute of FSIN Russia, Moscow, Russian Federation \\ ORCID: https://orcid.org/0000-0002-0030-4536, e-mail: kovtunenkolv@mail.ru

\section{ELENA I. MESHCHERYAKOVA} \\ Russian Air Force Military Educational and Scientific Center "Zhukovsky and \\ Gagarin Air Force Academy", Voronezh, Russian Federation \\ ORCID: https://orcid.org/0000-0003-3726-5283, e-mail: elenamsol@yandex.ru
}

\section{YULIYA G. KHLOPOVSKIKH}

Voronezh Institute of the Ministry of Internal Affairs of the Russian Federation, Voronezh, Russian Federation

ORCID: https://orcid.org/0000-0002-3775-9665, e-mail: flugel24@yandex.ru

\begin{abstract}
Introduction: the article analyzes professional marginalism, which became increasingly widespread in recent years. Preventing marginalism becomes an urgent issue for representatives of various scientific fields: sociologists, psychologists, and teachers. At the same time, there is still an insufficient amount of studies on the problems associated with the prevention of professional marginalism as a dangerous psychological phenomenon, despite their high social, national and personal significance. The development of professional marginalism is especially dangerous among employees of law enforcement agencies: military personnel, law enforcement officers, correctional officers, etc. The relevance of this topic is due to the increase in the number of officers who show signs of professional marginalism. Aim: we review theoretical data and experience in studying the problem of professional marginalism as a dangerous psychological phenomenon so as to show possible ways of its prevention and correction in the course of educational process at departmental universities. Methods: theoretical (analysis, synthesis, comparison, systematization, generalization of psychological and pedagogical literature on the research problem, modeling), empirical (survey, testing, experiment), qualitative and quantitative data processing. Results: in the course of the research we have revealed that among the interviewed cadets of departmental educational organizations, including the Federal Penitentiary Service of Russia, the majority $(69.0 \%)$ tend to show ambivalent feelings about the profession they are mastering; professional marginalism as the antipode of professional commitment is manifested in the majority of cadets $(71.4 \%)$ at the median level. Only a fifth of the surveyed cadets showed a low level of professional marginalism. Conclusions: having analyzed the results of the assessment of the state and dynamics of the level of professional identity in cadets, we see that the achieved indicators should be increased in order to prevent professional marginalism. It can be achieved by developing and implementing a program to increase the level of formation of the professional identity in cadets. The program should include activities, forms and methods of their organization and implementation, aimed at preventing professional marginalism among law enforcement officers. An essential role in preventing the emergence and development of this psychological phenomenon belongs to educational (especially pedagogical) activities of lecturers in the course of training specialists in departmental universities.
\end{abstract}

Keywords: professional marginalism; professional identity; prevention of professional marginalism; pedagogical means; educational process; departmental educational organization. 
13.00.01 - General pedagogy, history of pedagogy and education.

For citation: Kovtunenko L.V., Meshcheryakova E.I., Khlopovskikh Yu.G. Pedagogical aspects related to the prevention of professional marginalism as a dangerous psychological phenomenon in educational process at departmental universities. Penitentiary Science, 2021, vol. 15, no. 3 (55), pp. 684-690. DOI 10.46741/2686-97642021-15-3-684-690.

\section{Introduction}

So far, Russian researchers and teachers have not conducted any comprehensive studies of pedagogical aspects related to the prevention of professional marginalism. At the same time, for foreign researchers, "the topic of marginality is one of the most popular and developed topics in various fields of science" [8, p.7], according to S.V. Obolkina who comes to this conclusion on the basis of the analysis of the works of Z. Bauman, H. Viljoen, R. E. Park, K. Myalo, V. Turner, T. Shibutani, A. Farge, etc.

In Russia, philosophical analysis of the problem of marginality is contained in the works of M.K. Mamardashvili, V.S. Mart'yanov, S.V. Obolkina, Yu.N. Solonin, etc.

There are many sociological works on marginalism as a social phenomenon (I.P. Popova, S.P. Gurin, O.A. Kornilova, L.I. Kemalova, etc.). Psychologists (S.N. Vaitulevich, E.P. Ermolaeva, S.A. Minyurova, S.E. Polyakova, N.A. Sainakova, etc.) study marginalism as a psychological phenomenon; and legal scholars (S.I. Kirillov, O.V. Lobovikov, E.V. Sadkov, R.F. Stepanenko, etc.) investigate legal conditions for the emergence and implications of marginal behavior of an individual, as well as ways to overcome them by improving the current legislation.

The findings of psychological and pedagogical research are particularly important [12; 13] for identifying the possibilities of preventing professional marginalism as a dangerous psychological phenomenon in educational process at departmental universities.

When determining the relevance and significance of studying the pedagogical aspects of the problem of preventing professional marginalism in law enforcement officers, we draw attention to the following contradictions:

- on the one hand, proper performance of professional duties by military personnel, law enforcement officers, correctional officers, etc. is highly important for society, the state and its citizens, as well as officers' awareness of the importance of their professional activity and their responsibility for its results; on the other hand, some of them do not accept professional values, lose a sense of commitment to the profession, lose interest in the performance of pro- fessional duties and personal significance of the profession;

- on the one hand, officers develop their professional identity as a psychological phenomenon that is diametrically opposed to professional marginalism; on the other hand, teachers at departmental universities are not sufficiently ready to prevent the development of marginalism through the implementation of purposeful educational activities that would develop a high level of professional identity in graduates.

\section{The main part}

Researchers who study professional marginalism as a psychological phenomenon point out that professional marginalism, despite being much less studied than its opposite phenomenon of "professional identity", is a fairly common phenomenon, especially in socionomic professions.

In contrast to professional identity, which in a generalized form represents "identification with a specific profession and professional community" [3, p. 3], professional marginalism is a "behavioral and conceptual antagonist of professional identity", reflects one's personal position of rejection of professional mentality and non-involvement in one's own profession [5, pp. 69-70].

In contrast to E.P. Ermolaeva, researchers A.I. Kalashnikov and S.A. Minyurova consider professional marginalism as an antonym not of professional identity, but of professional commitment, that is, "a state of devotion and loyalty that arose on the basis of identification with the profession, reflecting a stable, unchanging and truthful attitude, including a willingness to make commitments and fully (emotionally and intellectually) give oneself to the profession or professional business" [6, p. 7].

S.N. Vaitulevich characterizes professional marginalism as a state of an individual in which they "have no clear rules of conduct and their values are blurred" and which is based on "instability, unregulated norms and values of the individual" [2, p. 63].

One of the most striking manifestations of professional marginalism is seen in a radical change in the way in which the specialist perceives an individual (a client, a patient, a stu- 
dent, a subordinate from among the personnel in law enforcement agencies): the attitude toward someone as the subject of professional activity gives way to that exclusively as the object of influence and manipulation. The behavior of a specialist differs from the professionally declared one; it is aimed at the implementation of non-professional personal goals that are different from socially and professionally acceptable ones. This is expressed in professional mistakes, disregard for the performance of official duties and their improper performance, the use of professional position in narrow personal interests, consumer attitude toward the profession.

Based on the analysis of the research of psychological scientists we can define a number of objective and subjective reasons that cause professional marginalism: instability of socioeconomic conditions; low level of socio-legal organization of the macrostructure of the profession; inversion of moral values in society, denial of professional values; reform processes at the level of the industry, department, organization, to which the specialist cannot adapt; leveling the social significance of professional activity and its results; intrapersonal conflict that arises when it is necessary to make a choice between performing professional activities that do not bring rewards and refusing to perform official duties even if there is a threat of sanctions; initially unformed professional identity (due to lack of aptitude for the profession, ineffective professional adaptation, etc.); destructive experience of professional crisis, etc.

Thus, we can assert that professional marginalism is a complex psychological phenomenon that arises due to objective reasons, that is, a phenomenon given in the experience and in available a priori forms of sensory contemplation [7], which requires a comprehensive analysis.

The study of pedagogical aspects of preventing professional marginalism in future specialists in the course of educational process at departmental universities is based on E.P. Ermolaeva's statement that professional marginalism develops under the influence of "violation of the ties of each pair in the triad "individual profession - society": violation of the "individual - profession" ties provokes a decrease in the socially acceptable level of professionalism; violation of the "individual - society" ties leads to an increase in the contradiction between the meaning and sense of the profession; when the "profession - society" relationship is violated, the threshold of moral prohibitions decreases" [4, p. 16].

It is advisable to start preventing the occurrence and development of these violations in the triad "individual - profession - society" in the course of educational process at departmental universities, where cadets embark on the path toward their chosen profession.

The pedagogical problem associated with the prevention of professional marginalism among future specialists of law enforcement agencies in connection with the violation of pairwise connections in this triad can be formulated in general as follows: how to ensure the formation of personal and professionally significant qualities in future specialists in the course of educational process at departmental universities, creating the basis for motivating the development of professionalism, a deep understanding of the meaning and significance of the profession, excluding the lowering of the "threshold of moral prohibitions", that is, preventing the formation and development of professional marginalism as a dangerous psychological phenomenon?

To answer this question, it is necessary to carry out comprehensive psychological and pedagogical research that should take into account that "scientific research", as A.N. Alyokhin points out, is, first of all, an analytical decomposition of the initial phenomenon into a set of elements to be considered" [1, p. 20].

In our work, we study the possibilities of preventing professional marginalism among future specialists in the educational process of departmental universities in the aspect of such "analytical decomposition" in accordance with the established triad "individual - profession society".

Speaking about the prevention of the violation of the "individual - society" ties, we can say that in this case cadets should understand the moral values inherent in representatives of the profession they have chosen; consequently, they should bear in mind that this understanding is important to society. Vladimir Putin has repeatedly drawn attention to the need to "strengthen in new generations the basic values that have been tested by life itself, which reflect our traditions, national identity, the entire historical path of Russia with its trials and triumph" [9].

The difficulties of forming basic values in the system of moral values of cadets at the present stage of social development are largely due to the fact that the system of values of young people, including cadets of departmental uni- 
versities, is currently undergoing significant changes [14]. Without going into the analysis of their causes, features and manifestations, we will speak about a number of the most typical aspects of philosophical and sociological research, which are reflected in young scientists' publications.

For example, K.S. Talanova is sure that "our country is in the deepest spiritual crisis, the traditional guidelines and meanings have been lost" [10, p. 179], I.N. Tkachenko, Z.V. Bersun'kaeva are convinced that "at present, young people are experiencing a decline in their values: difficult and inconsistent processes are taking place, indicating a revision of the set of values of previous generations" [11, p. 518].

Significant changes affecting the system of moral values require a revision of the content and forms of education of future specialists at departmental universities, where these values are formed mainly in the process of education. At the same time, it is important to preserve such fundamental things as loyalty to duty, honor, dignity, courage, love for the Motherland, high military discipline, etc. in the system of personal moral values.

The violation of the "profession - society" ties can be prevented if future specialists devel- op a system of moral values that are adequate to the requirements of their upcoming professional activity: humanism, responsibility, patriotism, citizenship, sociability, determination, honesty, justice, etc.

Preventing the violation of the "individual profession" relationship requires creating the foundations for the formation and development of professionalism. As a professional, an employee of law enforcement agencies should be able to solve the tasks set regardless of the conditions of the situation. The set of special knowledge, skills and abilities that characterize an officer includes competence, discipline, commanding will, organizational abilities, creative activity, psychological and physical qualities necessary in a particular type of activity.

In order to establish the state of professional identity of cadets at different stages of their professional education and to determine the level of professional commitment and professional marginalism, a pilot study was conducted with the participation of 42 cadets of Voronezh Institute of FSIN Russia. Having modified the Professional Commitment Questionnaire developed by A.I. Kalashnikova and S.A. Minyurova for the purposes of the study, we obtained the results presented in Table 1.

Table 1

Differentiated groups of cadets by the level of professional commitment and professional marginalism (in \%)

\begin{tabular}{|l|c|c|c|}
\hline Indicators $\quad$ Levels & High level & Median level & Low level \\
\hline Components of professional commitment & & & \\
\hline 1. Professional affectivity & 31.0 & 69.0 & 0.0 \\
\hline 2. Professional activity & 61.9 & 39.1 & 0.0 \\
\hline 3. Stability & 21.4 & 78.6 & 0.0 \\
\hline Professional marginalism & 8.5 & 71.4 & 20.1 \\
\hline
\end{tabular}

Based on the results obtained, we can conclude that professional commitment dominates professional marginalism in the vast majority of cadets. At the same time, the most pronounced driver of professional commitment is professional activity $(61.9 \%$ of cadets have a high level of formation of this component), which consists in the readiness to devote themselves intellectually and emotionally to the profession being mastered, the desire for professional self-improvement and maximum involvement in the activity.

Professional affectivity, which manifests itself in an emotionally positive attitude toward the profession, is formed at a high level in a third of cadets. These students feel a sense of pride from belonging to the profession, are emotionally attached to it and perceive the professional component as a harmonious part of their own personality. The majority of respondents $(69.0 \%)$ tend to show ambivalent feelings about the profession being mastered. Cadets from this group generally perceive their professional choice as the right one; they tend to internalize professional goals and values, which contributes to the formation of a professional mentality. They do not reject the profession, do not regard it as unacceptable for themselves, however, they do not feel pronounced affection and satisfaction. 
Professional stability, which reflects a sense of professional duty, awareness of the difficulty of leaving the profession due to significant time and energy investments in its development, is manifested in the majority of cadets $(71.4 \%)$ at the median level. The change of profession for these respondents is largely unacceptable precisely because of their reluctance to look for another place of study and subsequent work, and not because of the commitment to the profession. For one fifth of respondents, the most significant consequences of leaving the profession are the need to find another educational organization, the inability to realize certain needs in a new profession, the unwillingness to lose the time, energy, and other resources spent on mastering the current profession.

Professional marginalism as the antipode of professional commitment in the majority of cadets $(71.4 \%)$ is manifested at the median level. By the third year of training, future employees of the Federal Penitentiary Service of Russia have been participating in the educational and professional activities; moreover, they have obtained a certain level of professional mentality, and they are already experiencing some rejection of professional norms and values, a sense of non-involvement in the performance of the professional role that they are mastering. So far, they have not had the time to fully immerse themselves in professional activity, to realize its advantages and disadvantages; thus, they show a rather pronounced mental non-involvement in the profession.

Only one fifth of respondents show a low level of professional marginalism, which indicates that these cadets do not have self-denial in the profession, they do not consider it insignificant to them personally, and they do not have a sense of non-involvement in their future professional role.

Professional identity was assessed with the use of diagnostic tools suitable for the goals of an ascertaining experiment. The tools help to determine the levels of formation of the phenomenon under consideration as a whole and by its enlarged structural components - valuebased, activity-based and reflexive. In the process of diagnostics, the following techniques were used: the technique of life-meaning orientations by D.A. Leontiev and the technique of value orientations by $M$. Rokich - for the valuebased component; the technique of studying the status of professional identity by A.A. Azbel and the technique of identification research by B. Long, R. Ziller, R. Henderson for the activitybased component; the technique of reflexivity research by A.V. Karpov and the technique of diagnostics of the level of empathic abilities by V.V. Boyko - for the reflexive component.

Table 2 presents the results obtained using a 9-point rating scale, the values of which are distributed by levels (1-3 - low, 4-6 - median, 7-9- high).

Table 2

Average values of indicators of the degree of formation of professional identity in cadets of Voronezh Institute of FSIN Russia

\begin{tabular}{|l|c|c|}
\hline $\begin{array}{c}\text { Criteria for assessing the degree } \\
\text { of formation of professional } \\
\text { identity }\end{array}$ & \multicolumn{2}{c|}{$\begin{array}{c}\text { Changes in the average values of indicators for the enlarged } \\
\text { components of professional identity }\end{array}$} \\
\cline { 2 - 3 } & $\begin{array}{c}\text { intermediate testing (third year) } \\
\text { / initial testing (first year) }\end{array}$ & $\begin{array}{c}\text { final testing (fifth year) / } \\
\text { initial testing (first year) }\end{array}$ \\
\hline Value-based & $4.37 / 2.53$ & $5.06 / 2.53$ \\
\hline Activity-based & $4.02 / 2.44$ & $5.21 / 2.44$ \\
\hline Reflexive & $4.81 / 2.26$ & $5.04 / 2.26$ \\
\hline Total average value for all criteria & $4.40 / 2.41$ & $5.10 / 2.41$ \\
\hline
\end{tabular}

The following diagram gives a clear idea of the dynamics of the formation of professional identity in cadets:

The results obtained indicate that the cadets of the first year of training mainly have a low level of formation of professional identity (the average total indicator is 2.41). At the same time, the indicators of the value-based criterion are slightly higher than the average value, which is explained by the value-semantic orientations of applicants choosing a future profession. The value of the reflexive criterion indicators is significantly lower than the average, which is due to the fact that first-year cadets have not yet developed skills related to self-assessment and self-analysis of the process and results of activity in accordance with their chosen profession. The values of the indicators obtained based on the results of the intermediate testing conducted in the 3rd year of training indicate 


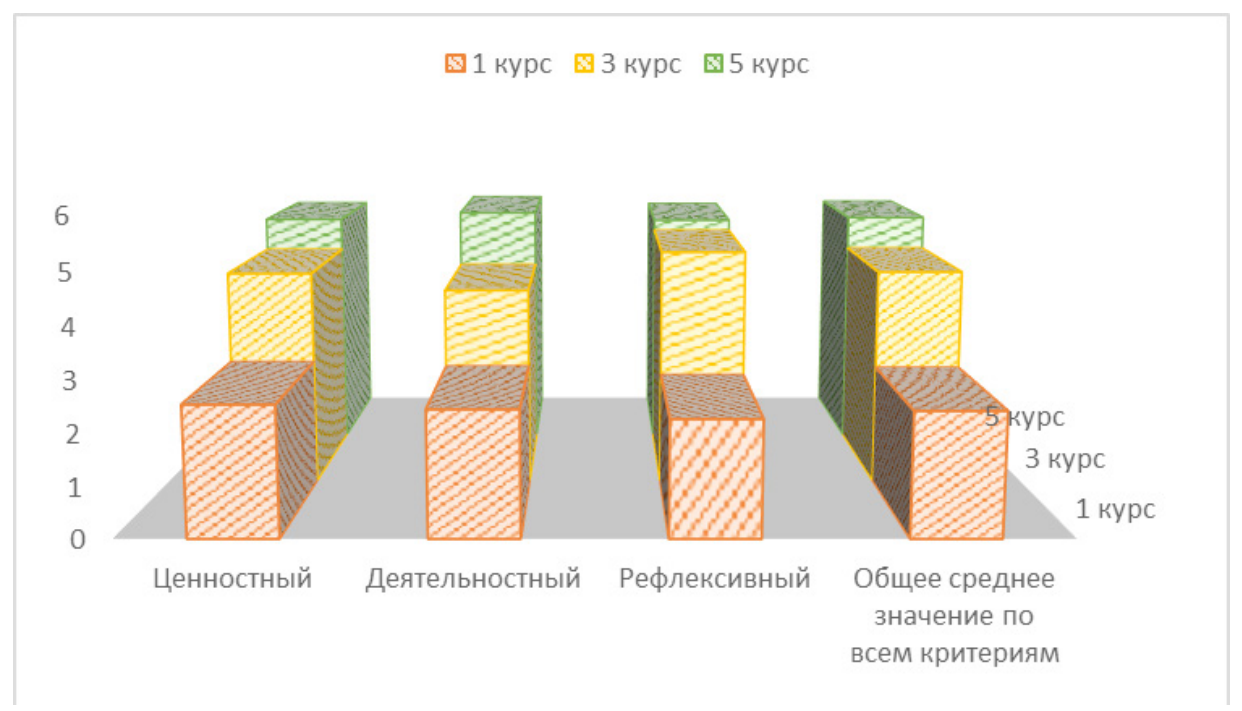

Fig. Dynamics of indicators of professional identity of cadets determined by the results of the diagnostics at the 1st, 3rd and 5th years of training

(1 курс - 1st year, 3 курс - 3rd year, 5 курс - 5th year, ценностный - Value-based, деятельностный - Activity-based, рефлексивный - Reflexive, общее среднее значение по всем критериям - Total average value for all criteria)

that the majority of cadets rise to the median level of professional identity formation, but are at its lower limit. At the same time, the indicators of the reflexive criterion reach higher values, which is largely due to the development of reflexivity and empathic abilities. At the same time, the indicators of the dynamics of the value-based criterion become the lowest, which indicates a change in the value orientations of cadets in educational process. The results of the final testing conducted in the 5th year of training confirm that the majority of cadets have achieved the median level of professional identity formation, but the values of the indicators are close to the upper limit determined for the median level. The highest were the values of the indicators of the activity-based criterion, which reflects a generally positive attitude toward the professional activity that graduates of a departmental university will have to perform.

\section{Conclusion}

In general, the analysis of the results of assessment of the state and dynamics of the formation of professional identity in cadets shows that its level should be increased in order to prevent professional marginalism. This requires the development and implementation of an appropriate program, including measures, forms and methods of their organization and implementation, aimed at preventing professional marginalism in law enforcement officers.

Unfortunately, a society of professional marginals is being formed among young people in Russia. Professional marginalism, which arises against the background of negativism toward society, the denial of many of its values, including professional ones, and the distortion of ideas about a decent lifestyle, becomes a social norm for young people. Potential marginals, as a rule, become either unemployed or active professional marginals, who do not care about professional satisfaction, because they perceive profession only as a means to earn money.

Prevention and correction of professional marginalism, in our opinion, should consist in restoring the professional identity of an employee, in simulating problematic pedagogical situations that develop creativity and responsibility and implement the need for recognition and satisfaction of professional ambitions. These goals can be achieved with the help of technologies for building individual trajectories and scenarios for professional development, psychological counseling and support, during which specific actions, difficulties, etc. are discussed. The use of interactive technologies will help to reduce professional destructions and increase the efficiency of professional activity of future officers. 


\section{REFERENCES}

1. Alekhin A.N. Psychological phenomenon as a methodological problem. Izvestiya Rossiiskogo gosudarstvennogo pedagogicheskogo universiteta im. A. I. Gertsena=Izvestia: Herzen University Journal of Humanities \& Sciences, 2013, no. 155 , pp. 16-22. (In Russ.).

2. Vaitulevich S.N. Marginal consciousness and behavior as an aspect of the socio-psychological organization of a marginal personality. Uspekhi sovremennogo estestvoznaniya=Advances in Current Natural Sciences, 2007, no. 2, pp. 60-81. (In Russ.).

3. Didenko A.A., Didenko I.V. Professional identity of servicemen of the internal troops of the Ministry of Internal Affairs of Russia. Psikhopedagogika v pravookhranitel'nykh organakh=Psychopedagogy in Law Enforcement Agencies, 2013, no. 4 (55), pp. 3-7. Available at: https://cyberleninka.ru/article/n/professionalnaya-identichnost-voennosluzhaschihvnutrennih-voysk-mvd-rossii (accessed November 29, 2020). (In Russ.).

4. Ermolaeva E.P. Multidisciplinary approach to the "person - profession - society" model. Institut psikhologii rossiiskoi akademii nauk. Organizatsionnaya psikhologiya i psikhologiya truda=Institute of Psychology of the Russian Academy of Sciences. Organizational Psychology and Labor Psychology, 2017, vol. 2, no. 1, pp. 3-22. (In Russ.).

5. Ermolaeva I.P. Professional identity and marginalism: the concept and reality. Psikhologicheskii zhurnal=Psychological Journal, 2001, vol. 22, no. 4, pp. 51-60. (In Russ.).

6. Kalashnikov A.I., Minyurova S.A. Professional commitment and professional marginalism in teachers. Psikhologicheskaya nauka i obrazovanie=Psychological Science and Education, 2017, vol. 22, no. 5, pp. 5-13. (In Russ.).

7. Mikhailov I.A. Phenomenon. In: Novaya filosofskaya entsiklopediya [New Philosophical Encyclopedia]. Available at: https://iphlib.ru/library/collection/newphilenc/document/HASHc26f429f6526f3c83ca4c2?p.s=TextQuery (accessed November 29, 2020). (In Russ.).

8. Obolkina S.V. Philosophical analysis of marginality problem. Nauchnyi ezhegodnik Instituta filosofii i prava Ural'skogo otdeleniya Rossiiskoi akademii nauk=Research Yearbook of the Institute of Philosophy and Law of the Ural Branch of the Russian Academy of Sciences, 2018, vol.18, no. 2, pp. 7-20. - DOI 10.17506/ryipl.2016.18.2.720. (In Russ.).

9. Vladimir Putin: a program for patriotic education should be based on core values. TASS website. Available at: https://tass. ru/obschestvo/7325009 (accessed December 17, 2020). (In Russ.).

10. Talanova K.S. Core of values spiritual and moral crisis: definitions, typologies, values. Vestnik Moskovskogo universiteta. Seriya 18: Sotsiologiya i politologiya=Moscow State University Bulletin. Series 18. Sociology and Political Science, 2014, no. 3, pp. 179-199. (In Russ.).

11. Tkachenko I.N., Bersun'kaeva Z.V. Problems of forming a system of moral values in modern Russian youth. Molodoi uchenyi=Young Scientist, 2017, no. 15 (149), pp. 518-520. (In Russ.).

\section{INFORMATION ABOUT THE AUTHORS}

LYUBOV' V. KOVTUNENKO - Doctor of Sciences (Pedagogy), Associate Professor, Senior Researcher at the Department for Development of the Methodology of Social, Psychological, Educational and Pedagogical Work with Convicts, Scientific Research Center-2, Research Institute of FSIN Russia, Moscow, Russian Federation, ORCID: https://orcid.org/00000002-0030-4536, e-mail: kovtunenkolv@mail.ru

ELENA I. MESHCHERYAKOVA - Doctor of Sciences (Pedagogy), Professor, Senior Researcher at Russian Air Force Military Educational and Scientific Center "Zhukovsky and Gagarin Air Force Academy", Voronezh, Russian Federation, ORCID: https://orcid.org/0000-0003-3726-5283, e-mail: elenamsol@yandex.ru

YULIYA G. KHLOPOVSKIKH - Candidate of Sciences (Psychology), Associate Professor, associate professor at the Department of Socio-Humanitarian Disciplines, Voronezh Institute of the Ministry of Internal Affairs of the Russian Federation, Voronezh, Russian Federation, ORCID: https://orcid.org/0000-0002-3775-9665, e-mail: flugel24@yandex.ru 